\title{
An Overview of Fruits and Vegetables Trade of China
}

\author{
Anam Azam $^{1 *}$ and Muhammad Shafique ${ }^{2}$ \\ ${ }^{1}$ Beijing language and culture university, China \\ ${ }^{2}$ Department of Smart City and Construction Engineering, Korea Institute of Civil \\ Engineering and Building Technology Campus, University of Science and \\ Technology, Korea \\ 1*Anamrafiq95@gmail.com, ${ }^{2}$ shafique@ust.ac.kr
}

\begin{abstract}
China is the most populated country to produce fruits and vegetables in worldwide and China participating in global trade. Horticulture is the means of cash crops for farmers. Food demand is increasing in China with huge population and Chinese government is trying to meet the domestic demand through new agriculture polices. China's participation in global trade represents that Chinese fruit and vegetables industry fasces international food security standards and increased inspection worldwide. The objective of this paper was to investigate the China's trade situation and how food safety standards in the importing countries impact the exports of vegetables and fruits from China. This research paper discussed the historical and current situation of fruits and vegetables of China. The result shows that in the past Chinese agriculture was not enough but now their government is improving agriculture system and making policies, plans and programs. Now China adopts the Euro GAP system and participating in international market. Furthermore, China's food safety standards also significantly effect on vegetables and fruits export.
\end{abstract}

Keywords: Agriculture, Exports, Imports, Fruits, Vegetables

\section{Introduction}

China reform was established in 1 Oct. 1949 with population of 1.3 billion which will increase 1.5 billion in 2030. China is the most populous country in the world and it is situated in Eastern Asia on the Western shore of the Pacific Ocean with 9.6 million SQKM Areas. China is in large size but only $13.2 \%$ is available for farmland [1]. China economic growth rapidly increased within short time period of about three decades that is often described by analysts as one of the best economic stories in modern times. Since the China's economic reforms, their economy has grown rapidly and most part has avoided major economic interruptions [2]. International trade and investment is an important part of the Chinese reform process. Within a very short time period, China thought to invest with the rest of the world and after few years, China's GDP started to increase by engaging with the outside world through internal exchange i.e. trade, investment flows, technology transfer, share experience and labor exchange. International trade and investment is an important part of the Chinese reform process [3]. China is the most populated country in the production of fruits and vegetables of the world and it is cash crops for farmers. Chinese farmers and exporters have evident, expected and positive impact on production and export of fruits and vegetables due to increasing consumer demands, income and the attainment to the world trade organization (WTO). China is the world's largest producer of fruit and vegetables and both markets are the largest segments

Received (October 27, 2017), Review Result (January 17, 2018), Accepted (February 1, 2018)

* Corresponding Author 
of the trade food market in China [4]. In the past, China's agriculture system was poor; however, there was no control for food safety and quality. But now China controlled the pests and disease problems to increase the yields due to boost the domestic demand. Fruit and vegetable industries improved rapidly due to increase the area and production in the last few years. Chinese government helps the farmers to become more prosperous and developing the rural economy of China. Moreover, they are paying more and more attention to food quality and food safety. China is on competition with other countries and great challenge for U.S industries. Since 1992, fruit production has increased in China and the national total production of fruit increased 84 MT in 2004. China participated in global trade and its fruits and vegetables market faces international market standards and open comparatively benefits of fruit and vegetables which significantly influenced on international regulations. China produced vegetables around 484 million tones and export 4.4 million tons, also China produce fruit 220 million tons and export only 3 million tons in 2012. It is estimated that China obtains half of the commercial from $30 \%$ production and become largest exporters in the world. China export value in fresh vegetables is forth and with fresh fruits they are counted in $7^{\text {th }}$ number [5].

A number of studies have examined China's fruits and vegetables at the national and regional level (e.g. Emilio P, 2011; Xiuxin 2005; Lei Dou et.al., 2013; Fred Gale 2006; Ton H et.al, 1998; Sophia H et.al., 2001). Moreover, two studies have examined on rural household food consumption across high, middle and low-income groups of China s. The result of these studies shows that different income groups have same consumption patterns and behavior. Economic theory suggests that household from different groups have different demand functions.

This paper examined the past and recent trends of China fruits and vegetables trade and highlights some of the factors contributing to these trends. This report also examined the exports and imports of fresh fruits and vegetables and what are the changes to produce fresh fruits during the past years in China.

\section{China Economic Performance}

The rapidity and scale of China's economic revolution have no historical example. Before 1949, China was poor country in the world and their GDP was very low relatively to U.S and other countries. According to the World Bank report, around 679 million people were extremely poor in China [6].

In 1949, China established new public reforms and develop policies for economic development which lead towards the economic growth rate. During 1953 to 1978, the total economic growth rate was around $4 \%$ that was the highest as compared to developing countries. In 1979, China started public reform and achieved an annual growth rate of $9 \%$ during 1979 to 1990 . According to the report in the early 2000s, Chinese researcher still believed that they could not continue the growth rate much longer due to lack of primary reforms (7). China annual growth rate increased 10.4\% during 1990-2010 and it became the world's second largest economy after the U.S and Germany. In 2012, China's GDP was $\$ 6075$, largest exporter and second largest importer of the world. Now China has become the global economic and the world largest economy based on purchasing power parity (PPP), manufacturer, exporter and importer and holder of foreign exchange reserves. China is the first country whose foreign exchange reserves added $\$ 3.3$ trillion in the world. Currently, China has become the beneficiary of largest Foreign Direct Investment (FDI) among the developing and under developed countries. It is estimated, China GDP was around 10\% from 1979-2014; (when economic reforms started) it means that its GDP increased in every eight years. But in 2015 it declined by $7.1 \%$ and in 2017 it will decline by $6.9 \%$.

In 1949, China established new public reforms and develop policies for economic development which lead towards the economic growth rate. During 1953 to 1978, the 
total economic growth rate was around $4 \%$ that was the highest as compared to developing countries [8]. In 1979, China started public reform and achieved an annual growth rate of $9 \%$ during 1979 to 1990 . According to the report in the early 2000s, Chinese researcher still believed that they could not continue the growth rate much longer due to lack of primary reforms. China annual growth rate increased 10.4\% during 19902010 and it became the world's second largest economy after the U.S and Germany. In 2012, China GDP was $\$ 6075$, largest exporter and second largest importer of the world. Now China has become the global economic and the world largest economy based on purchasing power parity (PPP), manufacturer, exporter and importer and holder of foreign exchange reserves. China is the first country whose foreign exchange reserves added $\$ 3.3$ trillion in the world. Currently, China has become the beneficiary of largest Foreign Direct Investment (FDI) among the developing and under developed countries. It is estimated, China GDP was around 10\% from 1979-2014; (when economic reforms started) it means that its GDP increased in every eight years. But in 2015 it declined by $7.1 \%$ and in 2017 it will decline by $6.9 \%$. The general information and economic indicators of China are summarized in Table 1.

Table 1. General Information about China and its Economic Indicators

\begin{tabular}{|c|c|}
\hline General Information (2015) & Economic Indicators (2015) \\
\hline Area & GDP (PPP): $\$ 19.39$ trillion \\
\hline Land : $9,326,410 \mathrm{sq} \mathrm{Km}$ & GDP real Growth Rate:6.9\% \\
\hline Water: $270,550 \mathrm{sq} \mathrm{Km}$ & Exports: $\$ 2.27$ trillion \\
\hline Total Area: $9,596,960 \mathrm{sq} \mathrm{Km}$ & Imports: $\$ 1.596$ trillion \\
\hline Agriculture Land: $54.7 \%$ & Annual Inflation rate: $1.4 \%$ \\
\hline Population: $1,370,708,000$ & Unemployment rate: $4.2 \%$ \\
\hline Currency: RMB-Chinese Yuan & Public Debt: $16.7 \%$ \\
\hline Language: Mandarin Chinese & Currency rate: 6.7044 \\
\hline
\end{tabular}
[9]

Source: International Monetary Fund, CIA Fact Book, official Government Statistics

China is playing an important role in the global economy; their government faces big challenge of balance of payment (BOP) in long-term and try to move the economy in short-term to support the economic growth. In the past, a large part of China population was in complex but gradually them familiar with the Chinese industries and participation in these markets. During 1980-1990, the consumers of urban middle class were almost fictional. Chinese Academy of Social Science (CASS) estimated that the total population of China 's middle class accounted for 19\% in 2003, but it will grow to 4\% in 2020 [10]. Currently, the consumers demand increased for luxury goods and services and most of the consumers belong to middle class segments who buy the high food including imported fruits and vegetables. China middle class growth leads towards the consumption of imported tropical fruits. Several decades ago, these imported tropical fruits were not available in China but now supermarkets have huge variety of imported tropical fruits to meet the consumption demand. China imported fruits and vegetables from Southeast Asia, Viet Nam, Philippines etc., but most of the vegetables consumed in China and are widely grown domestically. The imported fruits and vegetables enter different cities i.e. Shanghai, Ningbo, Tianjin, Guangzhou, Nanjing and Xiamen. Guangzhou is the big city having a wholesale market of fruits and vegetables and it is estimated that $70 \%$ of fruits imported into China. Fruit consumption is growing with the size of China middle class.

\section{Trend in Production of Fruits and Vegetables}

In 1980, after the economic reforms land productivity increased and technology change which caused the development of high yield crops and agriculture productivity growth. 
Total factor productivity in the crop sector grew by 2-3\% during 1980-2010. China 's food system is growing rapidly and food processing industry is also increasing, whereas it GDP in 2010 was $4.6 \%$.

\section{i. Government Policies to Enhance Production}

Government makes tax policy "Special Crops Tax" to support the farmers in order to increase income and under this policy, farmer needed to pay $12 \%$ of the income that was the much higher than the agriculture tax $6 \%$. Soon this policy abolished and still all agriculture farmers pay tax, there was no tax bias. But in 2006, government canceled the tax on all farmers, no need to pay tax because this policy does not help the farmers to increase the income. Government announced another policy "giving up the crops to forestry" under this policy, fruits and vegetables grew on hilly and mountain areas to protect the soil from erosion and keep for fresh water system. As a result, fruit crop and other vegetable crops production increased. Weather it is positive or negative improvement for crops but we need to bring further revolution. Now today's farmer is much more mature; have better production and market information system as compared to past years. Similarly, both local and central government made another policy to protect the land for annual growth crops to ensure the food safety. It is expected that China production will increase in the future but the structure will be change according to the market and different competitive areas. For instance, in two provinces Guangdong and Guangxi they changed the fruit production to increase the income. In Guangdong, they changed the lychee $\&$ citrus production and achieved very good income.

\section{ii. Variations in the scale of production}

China agriculture is representing the smallholder sectors with 200 million farmers. In the early 1980, successive market liberalization and rights to use farmland China decide what crops to produce and which crops will give more benefits to markets. At that time, Arable land cannot be bought and sold and domestic responsibility resulted in small and patchy farms. The total farm size was only 0.6 hectare with 3 to 4 main plots and $60 \%$ plots were less than 0.1 hectares in size [11]. Government made some policies to increase the small farms for agriculture growth and announced to use modern technology on small farms land plots [12]. So, to overcome small farm size, farmers use more and more land rental markets to adjust the scale of farm maneuver [13]. In China with farmer's cooperatives, agreement and vertical amalgamation their agribusiness increased rapidly [14]. In 2014, Chinese government announced that farmers enabled to transfers land rights to agribusiness and cooperation which facilitate hodgepodge of land plots and linked to rural and urban markets [15]. China is continuously trying to maintain the trend of rapid development in fruit and vegetable and its fruit volume reached 275 MT, an increase of $24.5 \%$ against the last years. During 2010-14, China apple production increased from 33.263 MT to 40.923 MT whereas other fruits i.e. Bananas; Oranges and Grapes etc. also keep very good annual growth impetus. However, the consumption of fruits is increasing with the increasing output volumes of fruit varieties. China fruit export was 3.043 MT, an increase of 3.5\%, but its export worth increases $19.5 \%$ annual in 2015. Similarly, China total import was $4.341 \mathrm{MT}$, an increase of $12 \%$. It represents that the competitive advantage of fruit has diminished in foreign markets, whereas the domestic consumption for standard fruits increased.

\section{iii. Renovation of Supply System}

Mostly China produced fresh fruit is still sold in traditional urban wet markets and the growth super- market trade has been increase rapidly. There are some issues China faced in the past which reduce the export and encourage the import 
First, recently China offers some kinds of fruits and vegetables with large volume for the export market. Fresh vegetables with high quality are available but their volume is limited (such as Singapore) where demand is satisfactory to support an operation.

Second, Chinese industry does not used grade standards which is important for international trade. Therefore, grade standards continually to encouraged imports and reduce export due to lack of specifications. Mostly private firms sold fresh products which are not based on specifications.

Third, there were no modern packing materials, packaging techniques and marketing practices. There were sufficient supply of labor with low cost production and slow capital improvements. Mostly Chinese market store fruits in ambient air and unimproved underground storage depths, which lead towards the corrosion. Now Processed and packaged food sales are increasing rapidly in China. Their supply system and two other system i.e. logistic and cold chains are increasing supply chains in western countries.

\section{iv. Land and water resources}

In China different provinces more arable land is in poor quality but in most areas soil macrobiotic matter is increasing [16]. Currently, urban residential and industrial land areas are improving, whereas productive farmland is also increasing. Chinese government announced that in order to keep food security system farmland areas should not plummet below 120 MHA (State council, 2008). In China, total water use for agriculture is about $62 \%$ and in many areas irrigation is dependent on groundwater which is declining significantly whereas, water which is used for agriculture remains low 45\% [17]. Agriculture also influenced from climate change and moreover reduction in water resources could decrease the agriculture production in future [18].

\section{v. Agricultural policies, Plans and Programs}

Chinese government make medium and long-term food security plan in 2008-2020 to stabilize the arable land area at $120 \mathrm{MHA}$; to maintain strategic grain reserves; to keep self-sufficiency at $>95 \%$ and to developed a modern grain logistic system. Government makes some programs for agriculture and food safety system i.e. to protect the arable land from renovation system; need to invest in water and irrigation infrastructure to increase the water efficiency from 0.5 in 2010 to 0.55 in 2020; use latest technology to increase crops area; and improved the agribusiness of China to invest overseas to make stronger the domestic food security. Some actions identified in the National Plan for Expansion of grain production (2009-2020) based on five year plans for modern agriculture development (2011-15) like to increase the area under the irrigation; to increase the irrigation techniques; increase the farmlands and to improve the agricultural mechanization. For example, Europe has good agriculture practice with more labor cost and consuming fresh fruits. European markets will have more fruits and vegetables in the future than other countries so, the GAP system is necessary for entering the markets. China is also trying to adopt the Euro GAP system and get the certification in order to export apple to Europe.

\section{Fruits and Vegetables Consumption}

Before 1978, China rural economy was $62.3 \%$ in food consumption and they produced less then consumption, only $48.3 \%$ of the food consumed in rural areas. After Chinese economic reform, their self-sufficiency decreased and China purchased and consumed more than $63.7 \%$ of the food. China self-sufficiency in vegetables and fruits decreased from $78.2 \%$ in 1980 to $51.3 \%$ in 1993 [19]. Now China is the largest food producer and food consumer in the world. During 2003, the total fruit production in China was $15.2 \%$ comparative to the world and it is the No. 1 producer in apple and pear added for $35.5 \%$ and 53\% respectively. Citrus production has been increased in China and their production 
was 16 MMT, around $16 \%$ and became the No.2 producer of the world after the Brazil [20]. Mostly the diversified climates influence the most kind of fruit crops in the world. According to the Ministry of Agriculture (MOA), the total fruit estate covered 9.769 million hectares with the production of 83.941 MMT during 2004-05. All fruits i.e. apple is the first famous fruit in China with the production of $23.675 \mathrm{MMT}$, followed by citrus 14.958 MMT and pear 10.642 MMT; the total production of three fruits added 58.7\% and the rest fruits shared left $41.3 \%$ in the last decades. Peach, Banana and Grapes are less important than other fruits in China and the total fruit production increased by $9.7 \%$ yearly but acreage rose by $1.5 \%$ only it means that their production increased rather than land. During 2011-12, China apple production was 35 MMT for marketing which was more than previous years and its acreage was 2.2 MHA. There is more arable land in Western provinces and cheaper labor cost rather than Eastern provinces. China 's top seven provinces i.e. Shaanxi, Shandong, Henan etc., have more acreage around $90 \%$ for planting and $85 \%$ for production and overall China 's fruit quality is increasing due to proper management offers. In the last decade, China fruits and vegetables consumption raised at a rate of $6 \%$ per capita and for fruits at $3.5 \%$ per capita. In last decades, the level of fruits and vegetable consumption in low income countries was less as compared to high income countries. In 2010, China vegetable consumption in rural areas was 93 and fruit consumption was 19.64 that were high as compared shows low consumption as compared to urban areas.

It is expected that the production of fruits and vegetables will grow in the future due to rising water and labor restraints. In 2011, $20 \%$ of the total crop area measured for these commodities, 12 MHA for fruits and 20 MHA for vegetables shown in this year. Labor and production cost are higher in Eastern provinces i.e. Shandong province labor is remunerated $100(\mathrm{RMB})$ per $(\$ 15.6)$ per day to work on harvest. China Production costs, i.e. fuel cost and agriculture inputs (pesticides and fertilizers) have increased. It is estimated that China total crops area will rise to 38 MHA by 2022 and straining area competition with other crops for insufficient water and land resources [21]. China fruits and vegetables consumption will raise in next year's see Figure 1. This figure shows that China consumption in vegetables is more than fruits.

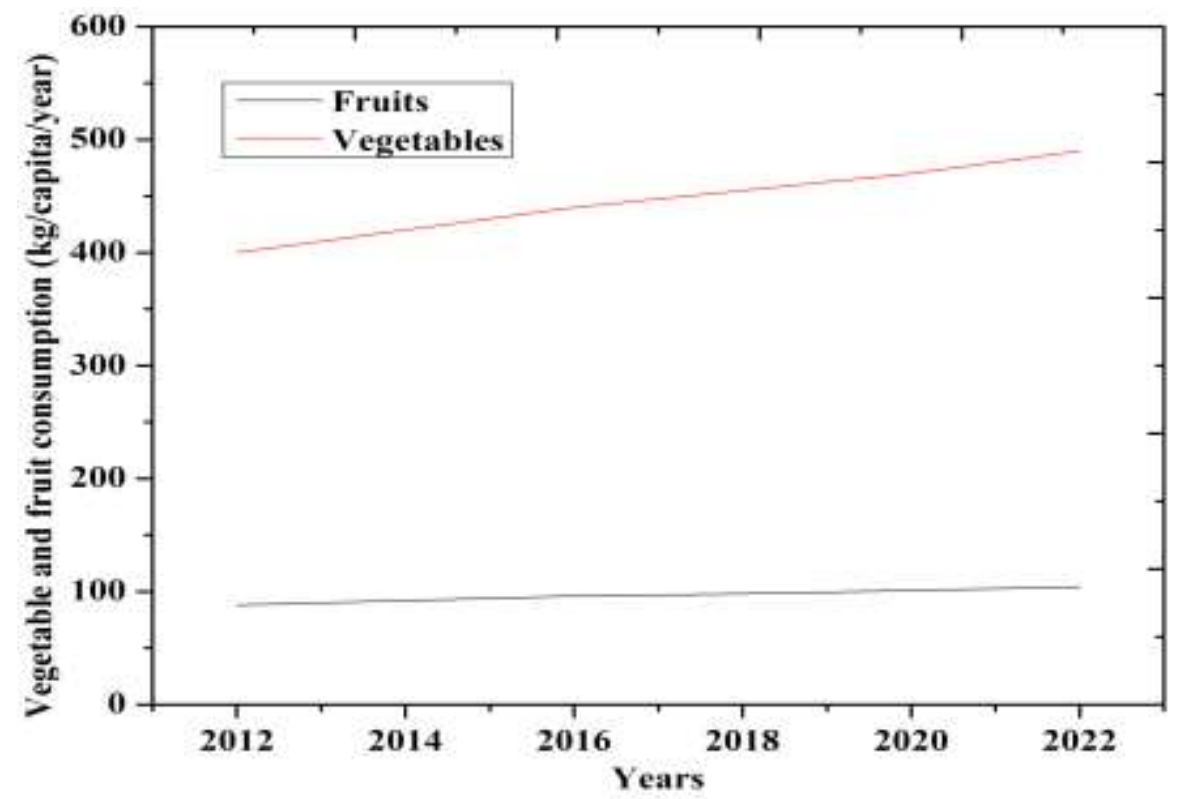

Figure 1. Fruits and Vegetables per Capita Consumption in China in (MT) Source: www.OECD-FAO.org [22] 


\section{Prices and Genesis}

In Shandong province fruit prices, i.e. apple remain unchanged at 5.6 to 6.4 (RMB) per kilo compared to the last years. Many China traders and prosperous purchasers stored apples for high profits in 2010-011. In the last years, fruit prices were high; but everyone surprised and there was no demand to support high prices so after the China New Year prices decreased by 4.0 RMB (\$0.63). Many apples which kept in storage could not sell and as a result traders suffered enormous loss. In the last few years, Grape prices increased but their production raised and equal to the demand so prices decreased. Xinjiang is the largest grape producers where grape prices rate are 5.8 RMB $(\$ 0.91)$ but in the last year's prick was 3.8 RMB (\$0.6) per kilo and the pears prices rate are 8.8 to 9.3 RMB. Mostly, fruit traders earned 30\%-50\% whereas in vegetable earned 20\%-50\%. Table 2 shows the fruits and vegetables prices of China different provinces in US $\$ / \mathrm{kg}$. This table shows that the prices of vegetables are expensive than other cities.

Table 2. Fruits and Vegetables Cost of Different Provinces

\begin{tabular}{|c|c|c|}
\hline Fruits/Vegetables & Origin & Prices (US\$/kg) \\
\hline Mango & Hainan province & $0.88-3.75$ \\
\hline Watermelon & $\begin{array}{c}\text { Zhejiang and Hainan } \\
\text { provinces }\end{array}$ & $0.26-0.76$ \\
\hline Pineapple & $\begin{array}{c}\text { Fujian, Hainan and } \\
\text { Guangdong provinces }\end{array}$ & $0.59-1.17$ \\
\hline Lettuce & Beijing, & $1.79-5.9$ \\
\hline Tomatoes & Beijing & $2-4-6.2$ \\
\hline Broccoli & Beijing & $1.50-5.1$ \\
\hline
\end{tabular}

Source: (Rabobank 2006) [4]

\section{Supply Chain}

Domestically China fruits and vegetables industry is playing an important role in agriculture sectors and increasing the export in the world. Since 1990s, China has significantly increased its position in the global market for fruits and vegetables and became one of the main producers of fruits and vegetables in China total export value in fruits and vegetables doubled between $1992-94$ and 2002-04, by $\$ 2.3$ to $\$ 5.1$ billion. Before 10 years China was poor country but now it has become huge exporter in international market. Mostly China export to Asian countries and U.S also export in these countries but U.S market share has declined due to rapidly export of China in number of markets. Due to lack of government involvement in advertising and charging of fruits and vegetables has resulted in an incorporated national market in China for many years. In 1996, prices are voluntarily conveyed athwart the country throughout production and marketing chains [23]. In the past, many private distributers were buying fruits and vegetables in the province of plentiful supply and selling them in scarcity regions. Many domestic producers of China were familiar about market information and demand diagonally the country so they set their prices according to the international markets. China fruit and vegetable supply chain is shown in Figure 2. 


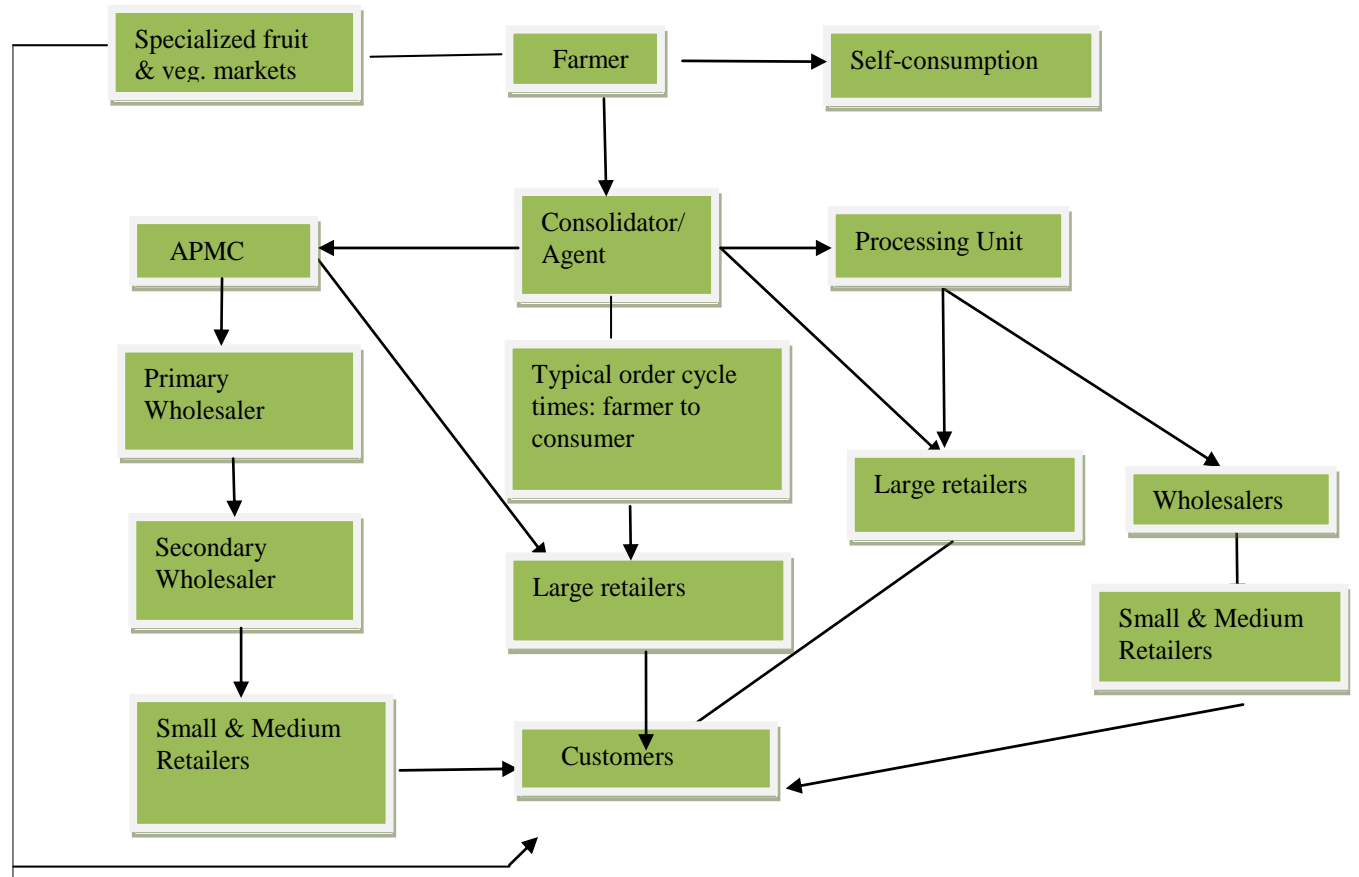

(Source. Rabobank (2006), APMC: Agriculture Produce Marketing Committee) [4]

Figure 2. China Fruit and Vegetable Supply Chain

China trade in fruits and vegetables heavily depend on the improvements of the domestic market i.e. how fresh domestic products increased in response to market enticement within China. In the 1990s, fruits and vegetables furnish have increased due to higher quality of production. Whereas, the quality of domestic products has recovered successfully and mostly marketers and growers focus on volume, "measured by weight not by the piece" especially in big cities like Hong Kong. China market and demand are depending on these factors i.e. income and population growth. China population is increasing $1 \%$ yearly or nearly 12 million per year and inflation adjusted income of urban resident more than doubled from 1990 to 2001. If we have higher income then we can consume more high quality of fruit with expenditures increasing $1.58 \%, 1 \%$ gain in income. Moreover, the expenditures of fruit by metropolitan occupant on peak $10 \%$ then the expenditures of those in the bottom $10 \%$ of income bracket are doubled. The consumption of fruits and vegetables has increased with huge population and rising incomes and according to the household survey China fruit consumption increased by 25\% (National Bureau of Statistics of China, 2002). Vegetables and fruits both are important in our life and vegetables use as a part of daily meals. Vegetables consumed more rather than fruits, as fruit are used only as a part of snack, meal and buy for gifts i.e. Chinese New Year or other holydays. Recently, fruit and vegetable prices are declining and other crops have been under greater pressure due to bad grain. If sowing enticements remain good as compared to other crops then fruits and vegetables will increase in future. China 's trade prospects are reinforcing relatively from low cost of production revealed in the wholesale prices. For instance, in Beijing the wholesale prices of fruits and vegetables are only $1 / 10^{\text {th }}$ to $1 / 3^{\text {rd }}$ as compared to the level of prices in other countries. However, high-quality products can reduce the cost advantages oblique by wholesale prices, yet many other private firms, i.e. foreign investors, labors and others who are getting benefits of China low input cost are increasing the fruit and vegetable output and overseas shipments. For example, China built a large packing export facility to ship lettuce, melons 
and celery to Japan and Singapore, it means that China will expand vegetable and fruit exports.

\section{China Trade in Fresh Fruits \& Vegetables}

After the economic reform in 1978, China started small trade with the rest of the world, exporting raw materials and simple manufactured goods to cover payments for imports. In 1980, China both exports and imports rose gradually and from 1980 to 1983 exports grew faster rather than imports which caused the export surplus. Since the end of 1980, China total trade was $\$ 115.4$ billion include 24\% of China GDP and 3\% of total world trade; now China is the $16^{\text {th }}$ largest trader in the world. During 1992-2001, China exports value of fruits and vegetables rose from \$2 billion to $\$ 3.7$ billion, but before 1992 the growth was slowed down and average prices decreased due to competition in markets. Approximately, the export volume of fruits and vegetables is around 1\% of total domestic output in China. China fruit and vegetable exports are progression products; the total value of fruit and vegetable exports was about $60 \%$ and $12 \%$ of global trade during 200204. The exports of fruit and vegetable products doubled between 1992-94 and 2002-04. In the last decade, China 's exports of fruit and vegetable was relatively small but during 2002-04 several frozen and processed fruit items i.e. jellies, jams, citrus, dried grapes etc rapidly increased. Whereas, Chinese fresh vegetable exports tripled between 1992-94 and 2002-04. During 2002-04, the average value of two products mushrooms and garlic was $\$ 481$ million per year and other fresh vegetable exports include onions $\$ 73$, carrots $\$ 46$, and radish $\$ 43$. Chinese fresh fruit and vegetable exports increased by $8 \%$ during 1992-94 to 2001-04 and fresh juices of fruit and vegetable accounts 6\% but rapidly growth in apple juice export represented a direct challenge for U.S producers. During 1992-94 to 2002-04, China total value of juice export grew from \$5 million to \$251 million per year and the global export value accounted for more than $18 \%$. Since 2001, China became the world's leading apple juice exporter. Recently, China is the largest trading partner of world and in 2015 China total trade was $\$ 598$ billion in goods and services. According to the Ministry of Commerce, in 2013 China fruit and nut export was 3.5\% and its total value increased by $\$ 4.318$ billion during 2014. In 2014, China produced 260 million tons of fruit and 700 million tons of vegetables and their export increased by $4.5 \%$ to the total value of $\$ 8.229$ billion. Table $3 \& 4$ represent the trade of fruit and vegetables and China major trading partners. In 2013/14, China export is more to US and South Korea.

Table 3. Vegetables \& Fruit Exports in Volume and Major Destinations (MT)

\begin{tabular}{|c|c|c|c|c|c|c|}
\hline \multicolumn{5}{|c|}{ Vegetables } & \multicolumn{3}{c|}{ Fruits } \\
\hline Country & $2012 / 13$ & $2013 / 14$ & $2014 / 15$ & $2012 / 13$ & $2013 / 14$ & $2014 / 15$ \\
\hline U.S & 716 & 727 & 480 & 26 & 18 & 21 \\
\hline Japan & 444 & 481 & 436 & 314 & 206 & 248 \\
\hline Taiwan & 267 & 228 & 223 & - & - & - \\
\hline South Korea & 891 & 1,022 & 737 & 423 & 374 & 225 \\
\hline France & 172 & 97 & 134 & - & - & - \\
\hline Thailand & 135 & 199 & 136 & - & - & - \\
\hline Others & 454 & 389 & 339 & 125 & 37 & 29 \\
\hline
\end{tabular}

Source. Global Trade Atlas [24]

In 2015, China shipped US\$2.282 trillion products value in the world. Now it is the world's largest exporter and China major trade partners are U.S, Hong Kong, Japan, and Germany etc. China global exports were $12.2 \%$ of $\$ 18.686$ trillion. In 2015, China total export worth $50.8 \%$ was delivered to other Asia countries, North American imports $20.8 \%$ and Africa imports $4.8 \%$ whereas $17.7 \%$ value delivered in European countries. China total export to 15 trade partners was $68.1 \%$ in 2015. From 2011-15, China two 
trade partners decreased the imports i.e. Germany $9.4 \%$ and Japan $8.3 \%$ down. But in other countries i.e. Vietnam, Malaysia, Singapore and Thailand importing value was high.

Table 4. Vegetables \& Fruit imports in Volume and Major Destinations (MT)

\begin{tabular}{|l|l|l|l|l|l|l|}
\hline \multicolumn{5}{|c|}{ Vegetables } & \multicolumn{3}{c|}{ Fruits } \\
\hline Country & $2012 / 13$ & $2013 / 14$ & $2014 / 15$ & $2012 / 13$ & $2013 / 14$ & $2014 / 15$ \\
\hline U.S & 524 & 528 & 338 & 2,298 & 4,191 & 6,422 \\
\hline Denmark & 791 & 860 & 1,378 & 383 & 365 & 409 \\
\hline Taiwan & 9 & 9 & 102 & 91 & 88 & 169 \\
\hline Japan & 454 & 394 & 353 & 423 & 374 & 225 \\
\hline Italy & 1,064 & 1,446 & 2,138 & - & - & - \\
\hline Thailand & 719 & 1,016 & 1,133 & - & - & - \\
\hline Others & 691 & 401 & 346 & 147 & 157 & 440 \\
\hline
\end{tabular}

Source. Global Trade Atlas [24]

\section{Conclusions and Swots}

China fruit and vegetable industries is an important and highly scrappy now. These industries show large growth both in production and export sectors. China fruit and vegetable production could be reduced due to limited available farmland. Chinese Government is trying to assure food quality and safety because these two factors are very important in food consumption and becoming major issue in China. Recent, regulations and control that are patchy, does not fulfill the needs of Western standards and farmer face hard rules and regulation because chemical pesticides which used are reduced. China is making plans and programs to improve the agriculture systems. The objective of Chinese government is that we must need to use modern technology in agriculture sectors for more and more trade with other countries and increase the farmer's income which is imbalance. Chinese government said that these factors will improve the economy, better organized and refined technology. The strengths, weakness, opportunities and threats to fruit and vegetable industry are as follows:

1. Strengths

- Income growth

- Low Labor Cost

- Government plans and programs for 5 years

- Position in the world market

- Juice production

- More production and exports for some fruit and vegetable varieties

2. Weakness

- Supply Chain

-post harvest loss

-low yield per hectare

- Food quality and safety

-Distribution and infrastructure

-Lack of infrastructure

- Farmland resources

3. Opportunities

-Improving Economic situation

- Growing domestic market

- Government focus on rural development

- High quality planting seeds

-Supply Chain management

- Food Quality management

-Education support in farming technique 
- Cold storage facilities

-Demand for exotic fruits

- Demand for fruit and vegetable seeds

- Increasing demand for green food and organic fruit and vegetables

- Demand for processed and frozen products

4. Threats

-Zero tariff ASEAN countries

-Land resources

-Food safety and quality scandals

- More international competition

-Stricter control in international trade

- Regulations by government

\section{Acknowledgment}

The authors sincerely thank all of the contributors and special thank to my husband Dr. M. Rafiq for his excellent contribution and participation.

\section{References}

[1] A Branson, "China's people Republic of new plant varieties protection", USDA Gain Report, (2005).

[2] China's Economic Reforms, "Third Plenum of the eleventh central committee of the communist party adopt Economic proposal", Implementation of the Reforms began in 1979, (1978).

[3] L. Song, "The Scale of China's Economic Impact",East Asia forum quarterly, vol. 2, no.1, (2010), pp. 68.

[4] Rabobank, "Food and agriculture research", www.industrianews.com, (2006).

[5] "China vegetable and fruit Production", www.freshplaza.com, (2012).

[6] The World Bank, "Development Challenges in the new Centaury", China 2020, Washington D.C.: World Bank, (1997).

[7] K. Akamatsu, "A Historical Pattern of Economic Growth in developing Countries", The Development Economics 1(Issue supplement s1), (1962), pp.3-25.

[8] International Monetary Fund, http://www.imf.org, (2009).

[9] International Monetary Fund, "IMF, CIA Fact Book, official Government Statistics", (2015).

[10] Faribank, "China's new History", Cambridge, MA: The Belknap Press, Harvard University Press, (1998).

[11] S. Huang, "China's rising fruit and vegetable exports challenge U.S", industries. Electronic outlook report from the economic research service FTS-320-01, ERS, USDA, (2006).

[12] S. Tan, "Evidence from rice farmers in Northeastern Jiangxi province", P.R China. China Economic Review, (2008), pp. 347-358.

[13] L. Gao, "Rental Markets for cultivated land and agriculture investment in China", Agriculture Economics, (2012), pp. 391-403.

[14] Q. Zhang, "The political economy of contract farming in China s agrarian transition", Journal of agrarian change, (2012), pp. 460-483.

[15] State council of the PRC, "Several onions on comprehensive deepening Rural Reform and Hastening Modernization of agriculture central Government Beijing China", State council of the PRC, (2014).

[16] Z. Xie, "Soil organic carbon stocks in China and changes from 1980s to 2000s", Global change Biology, (1989-2007).

[17] P. Wu, "Impact of climate change and irrigation technology advancement on agriculture water use in China", Climate change, (2010), pp. 797-805.

[18] L. Xing, "Estimating the non-commercial-commercial feed gap in China", University of llanos, (2009).

[19] A. Deaton, "Economics and Consumer behavior", Cambridge University Press, (1980).

[20] FAO, "Demand prospects for rice and other food grains in selected Asian countries", FAO, Economics and Social Development, no. 97, (1991).

[21] L. Christianensen, "Food security and Global Stability", Oxford University Press (forthcoming), (2013).

[22] OECD, "Agriculture policy and evaluation 2013", OECD countries and Emerging Economies, Paris 2013, (2013).

[23] The World Bank, "China options for reform in the grain sector", Washington DC. The World Bank, (1996).

[24] Global Trade Atlas, "CRS using data in the U.S", International Trade Commissions Trade Web Database. Fresh and processed Fruits as reflected in U.S. Harmonized Tariff Schedule (HTS). 


\section{Author}

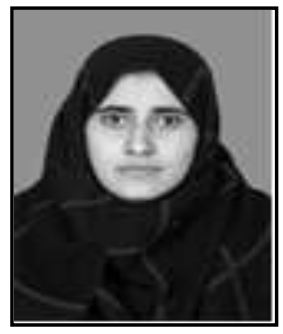

Anam Azam, she was born in Gujrat, Pakistan on 12 April 1991. She is currently doing her Master in Economics from Beijing Language and Culture University, Beijing. She has completed her BA in Economics (2010-2012) and MA in Sociology (2012-2014) from University of Gujrat, Pakistan. Her research interests include International Economy, Agricultural Economy, Educational Economy. 